\title{
APPLICATION OF TOPSIS METHOD TO SUPPLIER SELECTION IN IRAN AUTO SUPPLY CHAIN
}

\author{
Kambiz SHAHROUDI \\ S.Maryam Shafaei TONEKABONI \\ Islamic Azad University, Iran
}

\section{ABSTRACT}

In today's highly competitive environment, an effective supplier selection process is very important to the success of any manufacturing organization. In this context, supplier selection represents one of the most important functions to be performed by the purchasing department. Supplier selection is a multicriterion problem which includes both qualitative and quantitative factors (criteria). A trade-off between these tangible and intangible factors is essential in selecting the best supplier. A number of models and techniques have been developed to deal with selecting and evaluating suppliers. The aim of this study is developing a methodology to evaluate suppliers in supply chain cycle based on Technique for Order Preference by Similarity to Ideal Solution method (TOPSIS). The authors, with the help of going over expertise of experts and their relevant specialized literature, could recognize variables and effective criteria in supplier selection.

Keywords: Supplier selection problem, TOPSIS Method, supplier management, multi criteria decision making, supply chain management

\section{INTRODUCTION:}

Strategic management decisions impact all areas of a firm. Once such decisions have been made, the criteria for making subsequent operational decisions must be re-examined. New strategic directions may require new criteria and/or a re-emphasis of existing criteria used in making the operational decisions necessary to implement them. An important area of operational decision making is that of purchasing. In the current scenario of global competition, it has become indispensable for the manufacturers to cut down their fixed costs and deliver the goods at the right place in the right time to sustain the competition and survive the market. It is found from the past analysis that the raw material and component costs themselves carry $70 \%$ of the total cost. (Weber, Current, Benton, 1991)

A supply chain consists of all parties involved, directly or indirectly, in fulfilling a customer request. The supply chain not only includes the manufacturing and supplier, but also transporters, warehouses, retailers and customers themselves. The goal of Supply Chain Management (SCM) is to reduce cost and generate gains for every participating supply partners. The basic unit of a supply chin activity is:

Receive input from supplier $\rightarrow$ add value $\rightarrow$ deliver to customers

Suppliers have been acknowledged as the best intangible assets of any business organization (Chris I. Bell-Hanyes, 2010).

A supplier may be an external vendor or an upstream process within the firm. SCM requires the coordination of the flow of the products, services and information among SC entities such as supplier, manufacturers, distributors and customers (Toloei, Kalantay, 2011).

Selection supplier is a strategic decision in the course of supply chain management. The selection of suppliers depends on the sourcing strategy of the buyer/manufacturer. It help in optimizing the supply chain and thus increasing the efficiency of the supply chain. An incorrect supplier selection can drive the entire supply chain into confusion (Parthiban et al. 2010).

Lee et al. (2001) and Kumara et al. (2003) emphasize that selection of the best supplier is an essential strategic issue imperative for supply chain effectiveness and efficiency. Kumara et al. (2003) contend that strategic partnership with the right supplier must be integrated within the supply chain to contain 
costs, improve quality and flexibility to meet end-customers' value and reduce lead time at different stages of the supply chain (Chris I., Bell-Hanyes, 2010).

The main objective of supplier selection process is to reduce purchase risk, maximize overall value to the purchaser, and develop closeness and long-term relationships between buyers and suppliers, which is effective in helping the company to achieve "Just-In-Time" (JIT) production. Additionally, with the increase in use of Total Quality Management (TQM) and JIT concepts by a wide range of firms, the supplier selection question has become extremely important (Tahriri et al. 2008). Purchasing and supply management support the management of supplier network with respect to identification of supplier selection criteria, supplier selection decisions, and monitoring of supplier performance (Chris I., Bell-Hanyes, 2010).

According to Wang et al.(2008), supplier selection or evaluation is the process of finding the supplier who is able to provide the customer with the products or services that have the right quality, the right price, the right quantity and at the right time (Parthiban et al. 2010). Many approaches and algorithms are available that they have been used for supplier selection. Some of these algorithms are Analytical Hierarchy Process (AHP), Data Envelopment Analysis (DEA). Multi-Criteria Decision Making (MCDM) models have two major branches: Multi-Attribution Decision Making (MADM) and MultiObjective Decision Making (MODM) models. MADM models are good techniques for selecting a supplier, because many different factors play role in supplier selection problems. These factors usually have not same dimensions, for example price, delivery time, delivery reliability, reliability, quality and so on (Toloei, Kalantary, 2011). MCDM techniques support the decision-makers (DMs) in evaluating a set of alternatives (Tahir et al. 2008). One of the most reputed techniques of MADM models is TOPSIS (Technique for Order-Preference by Similarity to Ideal Solution). TOPSIS is a technique combines quantitative attributions (such as price, time, distance, and so on) and qualitative attributions (such as quality of relationship, quality assurance, reliability) and compares all alternatives together based on these attributions. TOPSIS is a powerful technique although it has a big weakness that is the fact that it doesn't provide us with a good alternative. According to this technique, the nearest alternative to the ideal solution is a suitable one. Now, the question is, where it origins from. The ideal solution, origins from the information of the available alternatives. Is there any assurance that the available alternatives are in suitable condition or not? Therefore, TOPSIS only is used whenever we want to select one alternative among others, regardless of suitability of the desired alternative (Toloei,Kalantari,2011). In the past decade, TOPSIS has been successfully applied to the areas of supplier evaluation and selection, inter-company comparison, expatriate host country selection, risk assessment, facility location selection, robot selection, operating system selection, software outsourcing problems, partner selection, customer evaluation, weapon selection, performance evaluation, etc (Jiang et al., 2010).

\section{Literature review}

Selection the right supplier for a long term relationship is a relevant procurement issue that demands judicious attention. According to Tahiri et al. (2008) "supplier selection problem has become one of the most important issues for establishing an effective supply chain system". Indeed, supplier selection and evaluation represents one of the significant roles of purchasing and supply management function. Tracey and Tan (2001) note that one of the key elements essential to supply chain success is effective purchasing function. Lee et al. (2001) and Kumara et al. (2003) emphasize that selection of the best supplier is an essential strategic issue imperative for supply chain effectiveness and efficiency. Kumara et al.(2003) contend that strategic partnership with the right supplier must be integrated within the supply chain to contain costs, improve quality and flexibility to meet end-customers' value and reduce lead time at different stages of the supply chain (Chris I., Bell-Hanyes, 2010).

A study by Moynihan et al.(2006), states that about $60 \%$ of the manufacturer's sales dollars are paid to the supplier for purchased materials. Automobile manufacturers spend about $60 \%$ of the total manufacturing cost, oil refineries about $80 \%$, food processor about $70 \%$ and farm equipment manufacturers about $65 \%$ on the supplier. Most of those costs occur in the first stage of supply chain i.e., supplier selection. As mentioned by Venkata Rao(2007), supplier performance is a key issue 
which affects the success or failure of organizations. Any supply chain is initiated with the selection of right suppliers for the raw materials (Parthiban et al. 2010).

Supplier selection decisions are complicated by the fact that various criteria must be considered in the decision making process. The analysis of criteria for selection and measuring the performance of suppliers has been the focus of many academicians and purchasing practitioners since 1960s.(Weber, Current, Benton, 1991) Based on Dickson's (1966) empirical study, 23 criteria were identified which purchasing managers generally consider when selecting a supplier. Of the identified criteria, quality, on-time delivery, and supplier's performance history were found vital in supplier selection regardless of the type of purchasing environment. Dempsey (1978) identified quality, delivery capability, and technical capability as imperative in supplier selection. Ellram (1990) emphasized the need not only to base supplier selection decision on the traditional price and quality criteria but also on longer term and qualitative attributes such as strategic match and evaluation of future manufacturing capabilities (Chris I., Bell-Hanyes, 2010).

\section{Table 1: Multiple approaches deployed for supplier selection problem}

\begin{tabular}{|c|c|c|}
\hline Category & Method & Refrences \\
\hline \multirow{3}{*}{$\begin{array}{l}\text { Artificial } \\
\text { Intelligence \& } \\
\text { Knowledge } \\
\text { Discovery }\end{array}$} & Genetic Algorithm & $\begin{array}{l}\text { Liao \& Rittscher (2007); } \\
\text { Chen \& Wang (2008); } \\
\text { Hwang \& Rau (2008) }\end{array}$ \\
\hline & Artificial Neural Networks & $\begin{array}{l}\text { Wei et al. (1997); } \\
\text { Wu et al. (2008); } \\
\text { Lee \& Ou-Yang (2009); } \\
\text { Chen et al. (2009) }\end{array}$ \\
\hline & Data Mining & Kai et al. (2009) \\
\hline \multirow{5}{*}{$\begin{array}{l}\text { Mathematical } \\
\text { Programming } \\
\text { Methods }\end{array}$} & Data Envelopment Analysis & $\mathrm{Wu}(2009)$ \\
\hline & Linear Programming & $\begin{array}{l}\text { Amid et al. (2006); } \\
\text { Guneri et al. (2009) }\end{array}$ \\
\hline & $\begin{array}{l}\text { AHP and Nonlinear } \\
\text { Programming }\end{array}$ & Kokangul \& Susuz (2009) \\
\hline & Rough set theory & Chang et al. (2007) \\
\hline & Grey system theory & Huixia \& Tao (2008) \\
\hline \multirow[t]{3}{*}{$\begin{array}{l}\text { MCDM } \\
\text { And } \\
\text { GMCDM }\end{array}$} & AHP & $\begin{array}{l}\text { Xia \& Wu (2007); } \\
\text { Lee (2009); } \\
\text { Chamodrakas et al. (2010) }\end{array}$ \\
\hline & ANP & $\begin{array}{l}\text { Gencer \& Gürpinar (2007); } \\
\text { Luo et al. (2009); } \\
\text { Razmi et al. (2009) }\end{array}$ \\
\hline & TOPSIS & $\begin{array}{l}\text { Boran et al. (2009); } \\
\text { Rhee et al. (2009) }\end{array}$ \\
\hline
\end{tabular}




\section{Table 2: Most common supplier selection criteria (Kasirian, Yusuff, 2009, Mohammady Garfamy, 2005, Zarbini-sydani et al. 2011)}

\begin{tabular}{|c|c|}
\hline Criterion & Researcher \\
\hline Quality & $\begin{array}{l}\text { Liu and Hai 2005; Shyur and Shih 2006; Jharkharia and Shankar 2007; Stevenson } \\
\text { 2007, Larson 1994; Tracey \& Tan 2001; Dzever, Merdji \& Saives 2001, Dzever, } \\
\text { Merdji \& Saives 200, Kotabe \& Murray 2001, Pi \& Low 2006, Narasimhan 2006, } \\
\text { Chen et al. 2006, Ha \& Krishnan 2008, Ng 2008, Gencer \&Gürpinar 2007, Demirtas } \\
\& \text { Üstün2008, Amid et al. 2009, Lee 2009, Li et al. 2007, Liao \& Rittscher 2007, } \\
\text { Hong et al.2005, Lee et al. 2009, Wadhwa\& Ravindran2007, Liu \& Hai 2005, } \\
\text { Kahraman et 2003, }\end{array}$ \\
\hline Price/ Cost & $\begin{array}{l}\text { Shyur, and Shih 2006; Jharkharia and Shankar 2007; Stevenson 2007; Wang et al.; Pi } \\
\text { \& Low 2006; Narasimhan 2006, Ng 2008, Gencer \& Gürpinar 2007, Demirtas \& } \\
\text { Üstün2008, Amid et al. 2009, Lee 2009, Li et al. 2007, Liao \& Rittscher 2007, Hong } \\
\text { et al.2005, Wadhwa\&Ravindran2007, Liu \& Hai 2005, }\end{array}$ \\
\hline $\begin{array}{l}\text { Delivery } \\
\text { Reliability }\end{array}$ & $\begin{array}{l}\text { Shyur and Shih 2006; Stevenson 2007; Wang et al. 2004; Hua et al.2007 ; Pi \& Low } \\
\text { 2006, Narasimhan 2006, Ha \& Krishnan 2008, Ng 2008, Gencer \& Gürpinar 2007, } \\
\text { Demirtas \& Üstün2008, Amid et al. 2009, Lee 2009, Li et al. 2007, Liao \& Rittscher } \\
\text { 2007, Hong et al.2005, Wadhwa\& Ravindran2007, Liu \& Hai 2005, Xia \& Wu } 2007\end{array}$ \\
\hline $\begin{array}{l}\text { Flexibility and } \\
\text { Responsiveness }\end{array}$ & $\begin{array}{l}\text { Liu and Hai 2005; Shyur and Shih 2006; Stevenson 2007; Wang et al.2004; lee } \\
\text { 2009, , Liao \& Rittscher 2007, Li et al. 2009, Liu \& Hai } 2005\end{array}$ \\
\hline Location & Stevenson 2007; \\
\hline Reputation & Jharkharia and Shankar2007; Stevenson 2007; \\
\hline Service & $\begin{array}{l}\text { Hua et al.2007; Ghodsypour and O’Brien 1998, Humphreys, Mak \& Yeung 1998; } \\
\text { Dzever, Merdji \& Saives 2001, Handfield 1994, Min 1994, Bevilacqua \& Petroni } \\
\text { 2002, Noordewier, John \& Nevin } 1990\end{array}$ \\
\hline Assets / Facilities & $\begin{array}{l}\text { Liu and Hai 2005; Shyur and Shih 2006; Wang et al.2004; Goffin, Szwejczewski \& } \\
\text { New 1997; Humphreys, Mak \& Yeung 1998, Pearson \& Ellram 1995; Dzever, Merdji } \\
\& \text { Saives 2001, Noordewier, John \& Nevin 1990; Bhutta \& Huq 2002; Bevilacqua \& } \\
\text { Petroni 2002, Ellram 1990, Bevilacqua \& Petroni 2002, Min } 1994\end{array}$ \\
\hline $\begin{array}{l}\text { Long-term } \\
\text { Relationship }\end{array}$ & $\begin{array}{l}\text { Liu and Hai 2005; Shyur and Shih 2006; Jharkharia and Shankar2007; Ellram 1990, } \\
\text { Dzever, Merdji \& Saives } 2001\end{array}$ \\
\hline Professionalism & Liu and Hai2005; Shyur and Shih2007; \\
\hline
\end{tabular}

\section{TOPSIS Method:}

TOPSIS (Technique for Order Preference by Similarity to an Ideal Solution) method is demonstrated by Chen and Hwang (1992). The basic principle is that the chosen alternative must have the shortest distance from the ideal solution and the farthest distance from the negative-ideal solution (Shirouyehzad, Dabestani, 2011).

\section{Numeral example:}

For a company that wants select its supplier, suppose the following criteria and characteristic as the most important items to focus: price, Time of doing project, Quality, Amount of equipment, Distance After consideration following decision matrix is obtained: 
Journal of Global Strategic Management | V. 6 | N. 2 | 2012-December | isma.info | 123-131 | DOI: 10.20460/JGSM.2012615779

\begin{tabular}{|c|l|l|l|l|l|}
\hline Criteria & Price(C1) & Time(C2) & Quality(C3) & Equipment(C4) & Distance(C5) \\
\hline Supplier1 & 80 & 12 & Very good & Good & 260 \\
\hline Supplier2 & 75 & 14 & Very good & Very good & 230 \\
\hline Supplier3 & 72 & 13 & Good & Sufficient & 50 \\
\hline Supplier4 & 65 & 15 & Sufficient & Sufficient & 140 \\
\hline
\end{tabular}

The quantitative decision matrix:

\begin{tabular}{|c|c|c|c|c|c|}
\hline Criteria & $\mathrm{C1}^{-}$ & $\mathrm{C} 2^{-}$ & $\mathrm{C}^{+}$ & $\mathrm{C} 4^{+}$ & $\mathrm{C}^{-}$ \\
\hline Supplier1 & 80 & 12 & 9 & 7 & 260 \\
\hline Supplier2 & 75 & 14 & 9 & 9 & 230 \\
\hline Supplier3 & 72 & 13 & 7 & 5 & 50 \\
\hline Supplier4 & 65 & 15 & 5 & 5 & 140 \\
\hline$\sqrt{\sum_{i=1}^{m} a_{i j}^{2}}$ & 146.40 & 27.09 & 15.36 & 13.41 & 377.62 \\
\hline$\sum a_{i j}$ & 292 & 54 & 30 & 26 & 680 \\
\hline
\end{tabular}

Step 1: Normalize the evaluation index as:

$n_{i f}=\frac{a_{i f}}{\sqrt{\sum a_{i f}^{2}}}$

\begin{tabular}{|c|c|c|c|c|c|}
\hline & $\mathrm{C}^{-}$ & $\mathrm{C}^{-}$ & $\mathrm{C}^{+}$ & $\mathrm{C}^{+}$ & $\mathrm{C}^{+}$ \\
\hline Alternatives & & & & & \\
\hline Supplier1 & 0.54 & 0.44 & 0.58 & 0.52 & 0.68 \\
\hline Supplier2 & 0.51 & 0.51 & 0.58 & 0.67 & 0.60 \\
\hline Supplier3 & 0.49 & 0.47 & 0.45 & 0.37 & 0.13 \\
\hline Supplier4 & 0.44 & 0.55 & 0.32 & 0.37 & 0.37 \\
\hline
\end{tabular}


Step 2: Calculate entropy measure of every index using the following equation:

$P_{i j}=\frac{a_{i j}}{\sum_{i=1}^{m} a_{i f f}}$

Where: $\mathrm{i}=1,2, \ldots, \mathrm{m} \quad \mathrm{J}=1,2, \ldots, \mathrm{n}$

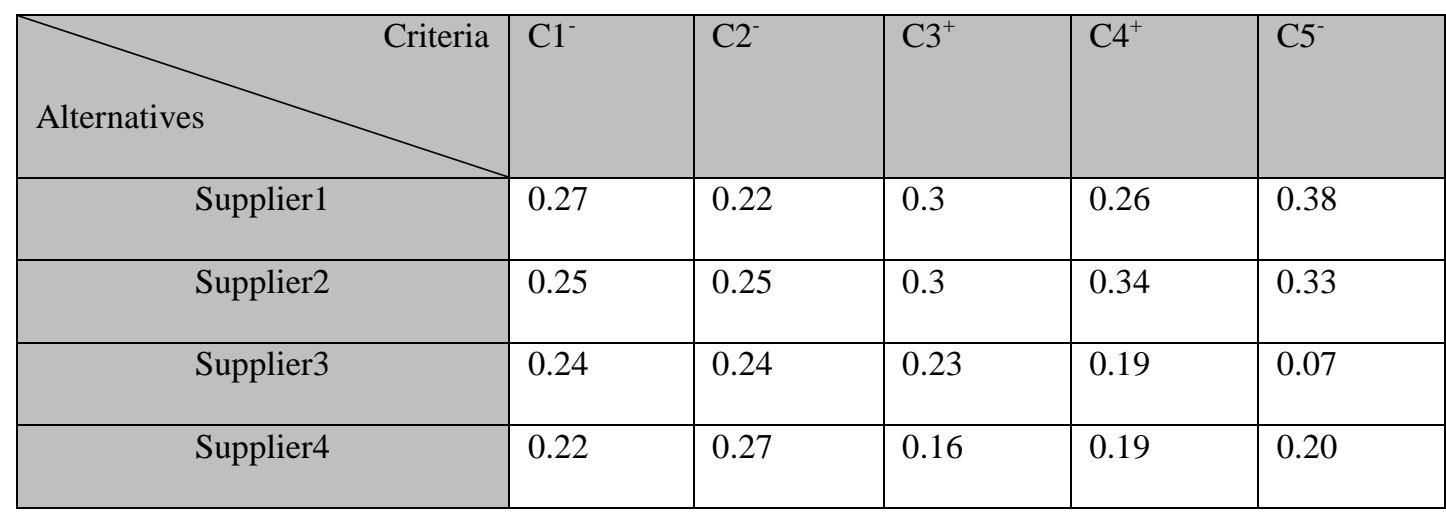

$E_{j}=-K \sum_{i}\left[P_{i j} \times \ln P_{i j}\right]$

Where; $K=\frac{1}{\ln (m)}$

\begin{tabular}{|ccccc|}
\hline E1 & E2 & E3 & E4 & E5 \\
\hline 0.97 & 0.97 & 0.96 & 0.95 & 0.87 \\
\hline
\end{tabular}

Step 3: Define the divergence through:

$$
\mathbf{d}_{\mathrm{j}}=\mathbf{1 - E _ { \mathrm { j } }}
$$

The more the $\mathrm{dj}$ is the more important the criterion $\mathrm{jth}$.

\begin{tabular}{|ccccc|}
\hline$d_{1}$ & $d_{2}$ & $d_{1}$ & $d_{4}$ & $d_{5}$ \\
\hline 0.03 & 0.03 & 0.04 & 0.05 & 0.13 \\
\hline
\end{tabular}

Step 4: Obtain the normalized weights of indexes as:

$W_{f}=\frac{d_{i}}{\sum d_{f}}$

\begin{tabular}{|lllll|}
\hline$W_{1}$ & $W_{2}$ & $W_{\mathrm{g}}$ & $W_{4}$ & $W_{5}$ \\
\hline 0.12 & 0.12 & 0.16 & 0.16 & 0.5 \\
\hline
\end{tabular}


Step5: Calculate the weighted normalized decision matrix. The weighted normalized value vij is calculated as:

$V=N \times W_{n \cdot m}$

$\left[\begin{array}{ccccc}0.54 & 0.44 & 0.58 & 0.52 & 0.68 \\ 0.51 & 0.51 & 0.58 & 0.67 & 0.60 \\ 0.49 & 0.47 & 0.45 & 0.37 & 0.13 \\ 0.44 & 0.55 & 0.32 & 0.37 & 0.37\end{array}\right] \times\left[\begin{array}{ccccc}0.12 & 0 & 0 & 0 & 0 \\ 0 & 0.12 & 0 & 0 & 0 \\ 0 & 0 & 0.16 & 0 & 0 \\ 0 & 0 & 0 & 0.16 & 0 \\ 0 & 0 & 0 & 0 & 0.5\end{array}\right]=$
$\left[\begin{array}{ccccc}0.06 & 0.05 & 0.09 & 0.08 & 0.34 \\ 0.06 & 0.06 & 0.09 & 0.1 & 0.3 \\ 0.05 & 0.05 & 0.07 & 0.05 & 0.06 \\ 0.05 & 0.06 & 0.05 & 0.05 & 0.18\end{array}\right]=$

Step6: Determine the ideal and negative-ideal solution:

$$
\begin{aligned}
& V_{f}^{+}=\left\{v_{i, \ldots}^{+}, v_{n}^{+}\right\}=\left[\left(\max _{i j} \mid i \in I^{-}\right),\left(\operatorname{minv}_{i j} \mid i \in I^{-}\right)\right] \\
& V_{f}^{-}=\left\{v_{i}^{-}, \ldots, v_{n}^{-}\right\}=\left[\left(\min _{i j} \mid i \in I^{-}\right),\left(\max _{i j} \mid i \in I^{-}\right)\right]
\end{aligned}
$$

Where I' is associated with advantage criteria, and I" is associated with cost criteria.

$V_{j}^{+}=\left[\min V_{i 1}, \min V_{i 2}, \max V_{i 3}, \max V_{i 4}, \min V_{i 5}\right]=[0.05,0.05,0.09,0.1,0.06]$

$V_{j}^{-}=\left[\max V_{i 1}, \max V_{i 2}, \min V_{i a}, \min V_{i 4}, \max V_{i 5}\right]=[0.06,0.06,0.05,0.05,0.34]$

Step7: Calculate the separation measures, using the $\mathrm{n}$-dimensional Euclidean distance. The separation of each alternative from the ideal solution is given as:

$$
\begin{aligned}
& d_{i}^{+}=\sqrt{\sum_{j=1}^{n}\left(v_{i j}-v_{j}\right)^{2}} i=(1,2, \ldots, m) \\
& d_{i}^{-}=\sqrt{\sum_{j=1}^{n}\left(v_{i j}-v_{f}\right)^{2}} i=(1,2, \ldots, m) \\
& d_{1}^{+}=0.28 d_{2}^{+}=0.23 d_{d}^{+}=0.06 d_{4}^{+}=0.013 \\
& d_{1}^{-}=0.05 d_{2}^{-}=0.07 d_{a}^{-}=0.28 d_{4}^{-}=0.16
\end{aligned}
$$

Step8: Calculate the relative closeness to the ideal solution. The relative closeness of the alternative aj with respect to $\mathrm{A}^{*}$ is defined as:

$$
\begin{aligned}
& C . L_{i}=\frac{d_{i}^{-}}{d_{i}^{-}+d_{i}^{+}} \quad I=1,2, \ldots, m \\
& C . L_{1}=\frac{0.05}{0.05+0.28}=0.15 \\
& C . L_{2}=\frac{0.07}{0.07+0.24}=0.22
\end{aligned}
$$


$C . L_{a}=\frac{0.28}{0.28+0.06}=0.82$

$C . L_{4}=\frac{0.16}{0.16+0.13}=0.55$

Step9: Rank the preference order:

\begin{tabular}{|c|c|c|}
\hline Alternatives & TOPSIS index & Rank \\
\hline Supplier1 & 0.15 & 4 \\
\hline Supplier2 & 0.22 & 3 \\
\hline Supplier3 & 0.82 & 1 \\
\hline Supplier4 & 0.55 & 2 \\
\hline
\end{tabular}

\section{CONCLUSION}

The study discussed that how to select the best supplier in supplier selection problems when decision makers set the target value of each criterion. Although many approaches can solve the problem, the study proposed a method and a procedure to extend the TOPSIS method to solve the problem. The main advantages of using TOPSIS method are "TOPSIS logic is rational and understandable", "The computation processes are straightforward", "The concept permits the pursuit of best alternatives criterion depicted in a simple mathematical" and "The importance weights are incorporated comparison procedures". Due to this, decision making for selection of suitable supplier is of special importance. Acquired results from numerical example determine that this model could be used for decision making optimization in supplier selection. 


\section{REFERENCES}

Chris I. E., Bell-Hanyes J., (2010), "a model for quantifying strategic supplier selection: evidence from a generic pharmaceutical firm supply chain", international journal of business, marketing, and decision sciences, vol. 3, no. 2

Jiang J., Chen Y.W., Tang D.W., Chen Y.W, (2010), "Topsis with belief structure for group belief multiple criteria decision making", international journal of Automation and Computing, vol.7,no.3, pp 359-364

Kasirian M.N., Yusuff R.M., (2009), "determining interdependencies among supplier selection criteria", European Journal of Scientific Research, vol.35, no.1, pp 76-84

Mohammady Garfamy R., (2005) "supplier selection and business process improvement", doctoral thesis, univesitat autonoma de Barcelona

Parthiban P., Mathiyalagan P., Punniyamoorty M., (2010), "optimization of supply chain performance using MCDM tool-a case study", int. J. value chain management, vol 4, no. 3

Shirouyehzad H., Dabestani R., (2011) " Evaluating Projects Based on Safety Criteria; Using TOPSIS", 2011 2nd International Conference on Construction and Project Management

IPEDR vol.15 Singapur

Tahriri, F., Osman, M. R., Ali, A., \& Mohd, R., (2008), "A review of supplier selection methods in manufacturing industries", Suranaree Journal of Science and Technology, vol.15, no.3, pp 201-208.

Toloei Eshlaghy A., Kalantary M., (2011), "Supplier selection by Neo-TOPSIS", applied mathematical sciences, vol.5, no. 17, pp 837-844

Wang YM, Elang TMS, (2006), "Fuzzy TOPSIS method based on alpha level sets with an application to bridge risk assessment", Expert Systems, vol.31, pp 309-319

Weber C.A., Current J.R., Benton W.C., (1991) "Vendor selection criteria and methods", European Journal of Operational Research 50, pp 2-18

Zarbini-Sydani A.H., Karbasi A., Atef-Yekta E., (2011), "evaluating and selecting supplier in textile industry using hierarchical fuzzy TOPSIS", Indian Journal of Science and Technology, vol.4, no. 10, $1322-1334$ 